\title{
AKSES UMKM KULINER TERHADAP PEMBIAYAAN MIKRO ( Studi di Pasar Semawis Kota Semarang )
}

\author{
Ong, Stefani Yunika Wijaya; Chatarina Yekti Prawihatmi ${ }^{1)}$ \\ 1) yekti@unika.ac.id \\ Jurusan Manajemen, FEB \\ UNIKA Soegijapranata Semarang
}

\begin{abstract}
ABSTRAK
Usaha Mikro, Kecil dan Menengah merupakan sektor usaha yang sangat berperan penting di Indonesia karena UMKM mampu meningkatkan kesejahteraan ekonomi Indonesia. Banyaknya pedagang mikro saat ini telah dapat membantu memberikan lapangan usaha dan mengurangi pengangguran. Namun permasalahan utama yang sering dihadapi pelaku UMKM adalah akses terhadap permodalan. Maka, akses modal yang mudah sangat dibutuhkan pelaku UMKM untuk mengatasi permasalahan tersebut dan demi mengembangkan usahanya.

Penelitian ini bertujuan untuk mengetahui akses pembiayaan mikro bagi pedagang mikro di Semawis, serta mengetahui faktor apa saja yang menjadi pendukung dan penghambat dalam mengakses pembiayaan mikro. Responden pada penelitian ini adalah pedagang mikro kuliner di Kawasan Pecinan, Waroeng Semawis Semarang yang berjumlah 12 orang. Teknik pengumpulan data dalam penelitian ini adalah melalui wawancara dipandu dengan kuesioner. Metode penelitian pada penelitian ini adalah metode kualitatif dengan pendekatan fenomenologi.

Hasil penelitian ini menunjukkan bahwa akses terhadap pembiayaan mikro dimiliki oleh pedagang kuliner Semawis. Pelayanan dan prosedur menjadi faktor pendukung akses pembiayaan mikro. Sedangkan agunan dan proses pencairan dana merupakan faktor penghambat dalam mengakses pembiayaan mikro bagi pedagang kuliner Semawis.
\end{abstract}

Kata Kunci : Usaha Mikro Kecil dan Menengah, Akses Pembiayaan Mikro, Pembiayaan Mikro, Lembaga Pembiayaan Mikro, Pinjaman Modal. 


\title{
CULLINARY MSMEs ACCESS TO MICRO FINANCING ( Study on Semawis Market Semarang City )
}

\author{
Ong, Stefani Yunika Wijaya dan Chatarina Yekti Prawihatmi ${ }^{1)}$ \\ 1) yekti@unika.ac.id \\ Jurusan Manajemen, FEB \\ UNIKA Soegijapranata Semarang
}

\begin{abstract}
Micro, Small and Medium Enterprises sector is a very important role in Indonesia because SMEs can improve the welfare of the Indonesian economy. Micro traders now are able to help provide field operations and reduce unemployment. But the main problem often faced by SMEs is access to capital. Therefore easy access to much needed capital SMEs to overcome these problems and in order to expand its business.

This study aims to determine access to microfinance for micro traders in Semawis, and to know what are the factors supporting and accessing microfinance. Respondent in this study is culinary micro traders in Chinatown area, Waroeng Semawis Semarang totaling 12 people. Data collection technique in this research is through interview guided by a questionnaire. The research method in this study is a qualitative descriptive method.

These results indicate that access to micro financing is owned by the merchant culinary Semawis. Services and procedures supporting factors access to microfinance. While collateral and the disbursement process is a limiting factor in access to microfinance to Semawis culinary merchants.
\end{abstract}

Key Words : Micro, Small and Medium Enterprise; Access Microfinance; Microfinance; Microfinance Institutions; Capital Loan. 


\section{PENDAHULUAN}

Pelaku bisnis di Indonesia sebagian besar adalah pelaku usaha mikro, kecil, dan menengah (UMKM). UMKM telah berperan signifikan bagi perekonomian Indonesia, yaitu sebagai penggerak ekonomi yang dapat menanggulangi pengangguran. Pertumbuhan UMKM beberapa tahun terakhir juga sangat signifikan. Tercatat dalam Laporan Tahunan Kementrian Koperasi dan UKM 2015, pada tahun 2011 jumlah usaha mikro, kecil dan menengah di Indonesia adalah sebesar 54.595.017 unit. Kemudian pada tahun 2012 meningkat yaitu menjadi 55.851.208 unit UMKM. Jumlah ini terus meningkat sejak tahun 2011 hingga tahun 2013 yang tercatat jumlah UMKM sebanyak 57.895.721 unit. Perkembangan jumlah UMKM yang pesat juga terjadi di Provinsi di Jawa Tengah. Sampai pada tahun 2015 tercatat sebanyak 108.937 unit UMKM di Jawa Tengah. Sementara di Kota Semarang, UMKM yang terdaftar di Kota Semarang pada tahun 2016 berjumlah 11.692 unit. Pertumbuhan jumlah UMKM di Kota Semarang rata-rata sebesar $1,97 \%$ per tahun.

Bagi pengusaha UMKM, terdapat berbagai masalah yang dihadapi antara lain masalah permodalan, sumber daya manusia, hingga pemasaran. Namun masalah utama yang sering dihadapi adalah masalah permodalan. Untuk dapat mengembangkan suatu usaha hal penting yang dibutuhkan adalah modal pendanaan usaha. Seperti yang diungkapkan Wakil Gubernur Jawa Tengah bernama Heru Sudjatmoko, masalah permodalan masih menjadi kendala utama bagi UMKM di Jawa Tengah. Serta dari sekitar 3 juta pelaku UMKM di Jawa Tengah, yang memiliki akses pinjaman ke perbankan tidak lebih dari 24 persen. Artinya belum seluruh pelaku UMKM dapat mengakses pinjaman mikro ini. Adapun pelaku UMKM yang tidak bisa mengembangkan usaha apabila hanya menggantungkan modal yang berasal dari milik sendiri, akan memerlukan pinjaman dari pihak lain. Maka dari itu untuk mengatasi masalah permodalan tersebut, berkembanglah Lembaga Keuangan Mikro (LKM). Lembaga keuangan mikro merupakan lembaga keuangan yang dikhususkan untuk usaha mikro yang bertugas menyalurkan pembiayaan berskala kecil yang dapat berperan sebagai penyalur kredit bagi usaha mikro yang tidak dapat memenuhi persyaratan perbankan. Sehingga para pedagang yang tidak dapat mengakses permodalan dari bank ini dapat mencari sumber dana dari lembaga keuangan mikro ini. Penelitian ini berfokus pada bagaimana akses para pelaku UMKM terhadap pembiayaan mikro khususnya para 
pedagang kuliner di Kawasan Pecinan Semawis Kota Semarang.Maka permasalahan yang dieksplorasi dalam penelitian ini adalah; 1) bagaimana akses UMKM kuliner di kawasan Pasar terhadap pembiayaan mikro, 2) lembaga pembiayaan mikro manakah yang dikenal dan dapat diakses oleh UMKM kuliner Pasar Semawis, 3) faktor apa saja yang mendukung dan menghambat UMKM Kuliner Pasar Semawis dalam mengakses pembiayaan mikro, 4) apakah pembiayaan mikro mampu menstimulasi kinerja usaha UMKM kuliner Pasar Semawis.

\section{TELAAH PUSTAKA}

\section{Pengertian Akses}

Menurut Kamus Besar Bahasa Indonesia (KBBI), akses berarti jalan masuk. Kata akses berasal dari bahasa Inggris yaitu "access" yang berarti jalan masuk, maka akses merupakan jalan atau izin masuk dari suatu tempat/wilayah baik dari yang dapat dilihat ataupun tidak dapat dilihat dengan mata kita dimana dapat berhubungan dengan sumber daya yang ada di dalam wilayah tersebut sesuai izin.

\section{Permodalan}

Permodalan merupakan salah satu hal terpenting untuk memulai suatu usaha, membuat usaha menjadi berkembang lebih besar. Modal merupakan barang atau alat yang digunakan untuk memulai kegiatan usaha. Modal dapat berupa modal uang, modal tenaga kerja, modal alat, dan lain-lain. Modal berupa uang digunakan untuk membiayai keperluan suatu usaha seperti modal kerja.

Sumber modal dapat berasal dari berbagai sumber seperti modal sendiri, modal asing / modal pinjaman. Modal sendiri adalah modal yang berasal dari milik sendiri. Sedangkan modal asing adalah modal yang sumbernya dari luar seperti bank atau lembaga keuangan bukan bank.

\section{Sumber - Sumber Modal Bagi UMKM}

Sumber Pembiayaan untuk UMKM dapat berasal dari dana pemerintah dan dana masyarakat. Dana pemerintah disalurkan melalui bank atau lembaga pemerintah lainnya (kredit disalurkan melalui BRI, BTN, PT). Sedangkan dana masyarakat/swasta disalurkan melalui lembaga keuangan bank/non-bank (diantaranya adalah perusahaan Modal Ventura, Yayasan, Lembaga Keuangan Mikro). 
Sumber pembiayaan bagi UMKM menurut UU No. 20 Tahun 2008 Pasal 21) dapat berasal dari :

1) Pemerintah dan Pemerintahan Daerah menyediakan pembiayaan bagi UMK.

2) Badan Usaha Milik Negara menyediakan pembiayaan dari penyisihan bagian laba tahunan yang dialokasikan kepada Usaha Mikro dan Kecil dalam bentuk pinjaman, penjaminan, hibah, dan pembiayaan lainnya.

3) Usaha Besar nasional dan asing dapat menyediakan pembiayaan kepada Usaha Mikro dan Kecil dalam bentuk pemberian pinjaman, penjaminan, hibah, dan pemberian lainnya.

4) Pemerintah, Pemerintah Daerah dan Dunia Usaha dapat memberikan hibah, mengusahakan bantuan luar negeri, dan mengusahakan sumber pembiayaan lain yang sah serta tidak mengikat.

5) Pemerintah dan Pemerintah Daerah dapat memberikan insentif dalam bentuk kemudahan persyaratan perizinan, keringanan tarif sarana dan prasarana, dan bentuk insentif lainnya yang sesuai dengan ketentuan peraturan perundangundangan kepada dunia usaha yang menyediakan pembiayaan bagi Usaha Mikro dan Kecil.

\section{Pembiayaan Mikro}

Peran pembiayaan mikro adalah mengentas kemiskinan, dilakukan dengan menyediakan fasilitas pinjaman kepada usaha mikro kecil produktif berpenghasilan rendah yang belum terjangkau oleh lembaga pembiayaan seperti bank. Mendorong pertumbuhan ekonomi, dilakukan dengan pemberian kredit dengan bunga kecil agar dapat mendorong sektor usaha mikro dan mengurangi angka pengangguran.

Lembaga Pembiayaan mikro di Indonesia terbagi menjadi LKM formal (bank) antara lain: BPR, BNI, BRI Unit, Danamon Simpan Pinjam, Mandiri Unit Mikro, BKD. LKM formal (nonbank) antara lain: koperasi simpan pinjam, koperasi unit desa, pegadaian.. LKM informal antara lain: Lembaga Swadaya Masyarakat (LSM), Baitul Mal wat Tamwil (BMT), rentenir, kelompok arisan. 


\section{Definisi Usaha Mikro Kecil dan Menengah}

Menurut Undang-Undang Nomor 20 Tahun 2008, pengertian beserta kriteria UMKM sebagai berikut;

Usaha mikro adalah usaha produktif milik orang perorangan dan/atau badan usaha perorangan yang memenuhi kriteria Usaha Mikro yang diatur oleh UndangUndang sebagai berikut;

a. Memiliki kekayaan bersih paling banyak Rp 50.000.000,00 (lima puluh juta rupiah) tidak termasuk tanah dan bangunan tempat usaha; atau

b. Memiliki hasil penjualan tahunan paling banyak Rp 300.000.000,00 (tiga ratus juta rupiah).

Usaha Kecil adalah usaha ekonomi produktif yang berdiri sendiri yang dilakukan oleh orang perorangan atau badan usaha yang bukan merupakan anak perusahaan atau bukan cabang perusahaan yang dimiliki, dikuasai atau menjadi bagian baik langsung maupun tidak langsung dari usaha menengah atau usaha besar yang memenuhi kriteria Usaha Kecil:

a. Memiliki kekayaan bersih lebih dari Rp 50.000.000,00 (lima puluh juta rupiah) sampai dengan paling banyak Rp 500.000.000,00 (lima ratus juta rupiah) tidak termasuk tanah dan bangunan tempat usaha; atau

b. Memiliki hasil penjualan tahunan lebih dari Rp 300.000.000,00 (tiga ratus juta rupiah) sampai dengan paling banyak Rp 2.500.000.000,00 (dua milyar lima ratus juta rupiah).

Usaha Menengah adalah usaha ekonomi produktif yang berdiri sendiri, yang dilakukan oleh orang perorangan atau badan usaha yang bukan merupakan anak perusahaan atau cabang perusahaan yang dimiliki, dikuasai, atau menjadi bagian baik langsung maupun tidak langsung dengan Usaha Kecil atau Usaha Besar yang memenuhi kriteria:

a. Memiliki kekayaan bersih lebih dari Rp 500.000.000,00 (lima ratus juta rupiah) sampai dengan paling banyak Rp 10.000.000.000,00 (sepuluh milyar rupiah) tidak termasuk tanah dan bangunan tempat usaha; atau

b. Memiliki hasil penjualan tahunan lebih dari Rp 2.500.000.000,00 (dua milyar lima ratus juta rupiah) sampai dengan paling banyak Rp 50.000.000.000,00 (lima puluh milyar rupiah) 


\section{METODE}

Obyek dalam penelitian ini adalah UMKM Kuliner di Kawasan Pecinan Kota Semarang (Semawis). Populasi dalam penelitian ini ditujukan kepada pedagang di Kawasan Pecinan (Semawis) yang berdasarkan hasil survey berjumlah 115 pedagang.

Pemilihan sampel menggunakan metode random sampling. Unit analisis atau disebut juga sebagai sampel terdiri dari informan kunci (key informan) dan informan pendukung. Informan kunci adalah UMKM kuliner Semawis yang terdiri dari UMKM yang mengakses pembiayaan mikro dari lembaga keuangan baik bank maupun nonbank ataupun dari sumber lainnya, serta sebagian lagi yang tidak mengakses pembiayaan mikro. Sedangkan informan pendukungnya adalah pengelola Semawis.

Jenis data yang digunakan dalam penelitian ini adalah data primer dengan teknik pengumpulan data melalui wawancara mendalam dan dipandu dengan kuesioner. Metode analisis data yang digunakan adalah analisis kualitatif. Menurut Miles dan Huberman terdapat 3 tahap yaitu: Pertama, Reduksi Data yaitu setelah mengumpulkan dan mencatat data di lapangan, data tersebut dirangkum kemudian dipilih hal pokok dan penting agar dapat memperoleh gambaran dari hasil penelitian. Kedua, Penyajian Data dilakukan dalam bentuk tabel, grafik, diagram atau sejenisnya disertai uraian singkat naratif agar dapat mempermudah pemahaman dari hail penelitian. Ketiga, Penarikan Kesimpulan yaitu menarik kesimpulan berupa deskripsi yang jelas untuk dapat menjawab rumusan masalah penelitian.

\section{HASIL DAN PEMBAHASAN}

\section{Profil Responden}

Informan kunci dalam penelitian ini adalah 12 UMKM Kuliner di Pasar Semawis yang berjualan makanan maupun minuman khas Semarang antara lain soto ayam, bakcang, tahu gimbal, pukis bikang, ayam geprek, es hawa, es gempol, dan liang tea.

Menurut jenis kelamin, sebesar 83,33\% pelaku UMKM kuliner yang berjualan di Pasar Semawis adalah perempuan. Berdasarkan usia, sebanyak 63,32\% responden di kelompok usia 40-49 tahun. Dalam kelompok usia tersebut berarti mampu bekerja secara aktif, memiliki tingkat kedewasaan dan pemikiran yang matang dalam hal mengelola suatu usaha. Menurut pendidikan, sebesar 50\% pelaku UMKM kuliner di 
Pasar Semawis berpendidikan terakhir jenjang SMA/sederajat, sedangkan yang berjenjang sarjana (S1) sebanyak 33,33\%. Hal ini menunjukkan bahwa sebagian besar pedagang di Semawis telah memiliki pendidikan yang memadai. Melalui pendidikan yang telah didapatkan, maka mereka dapat mengelola usaha dengan baik. Berdasarkan lama usaha, rata-rata pelaku UMKM Kuliner di Pasar Semawis telah berjualan sejak Pasar Semawis didirikan pada tahun 2004 , yang berarti kurang lebih sudah 11 tahun lamanya. Menurut tenaga kerja yang dimiliki, sebesar 33,33\% pedagang memiliki 5 orang tenaga kerja dan $66,67 \%$ memiliki kurang dari 5 tenaga kerja.

Rata-rata omzet para pelaku UMKM Kuliner di Pasar Semawis berkisar antara Rp.6.000.000-9.000.000 per minggu nya. Sumber modal dapt beragam asalnya, modal sendiri atau modal pinjaman. Masalah keterbatasan modal dapat menjadi hambatan bagi pedagang untuk mempertahankan usahanya. Berdasarkan modal yang digunakan $66,66 \%$ responden pedagang menggunakan sumber modal yang berasal dari milik sendiri. Sisanya terdapat 33,33\% responden yang mengakses modal dari pihak luar / pinjaman. Modal pinjaman di sini berasal dari lembaga keuangan perbankan. Maka sebagian besar pedagang yang berjualan di Semawis menggunakan modal sendiri.Hal ini menimbulkan pertanyaan apakah para pelaku UMKM di Pasar Semawis tidak memiliki akses modal dari luar lalu hanya menggunakan modal seadanya yang mereka miliki atau para pelaku UMKM Kuliner di Pasar Semawis tersebut memang sudah mencukupi dengan modal sendiri.

\section{Akses Terhadap Pembiayaan Mikro}

Berdasarkan survey yang diperoleh, seluruh responden pedagang kuliner di Semawis menyebutkan bahwa mereka mengenal adanya lembaga pembiayaan yang menawarkan kredit bagi usaha mikro. Para pedagang pernah mendapatkan tawaran secara langsung atau melalui media cetak. Maka, akses terhadap pembiayaan mikro sebenarnya sudah didapatkan para pedagang.

Meskipun semua pelaku UMKM Kuliner di Pasar Semawis telah memiliki akses pembiayaan yang mudah, namun hanya sebesar $60 \%$ responden yang menyatakan menggunakan/mengakses pinjaman modal dalam skim pembiayaan mikro dari berbagai lembaga keuangan. 


\section{Pembiayaan Mikro yang Dikenal dan Diakses}

Banyak lembaga keuangan yang menawarkan kredit berskala mikro untuk usaha kecil yang membutuhkan modal usaha termasuk di kawasan Pasar Semawis. Lembaga keuangan tersebut terbagi atas lembaga keuangan perbankan dan non perbankan. Dengan adanya lembaga tersebut tentu akan mendukung perkembangan ekonomi suatu daerah. Menurut survey, para pedagang mengetahui lembaga keuangan mikro yang berasal dari perbankan, antara lain : BRI (Bank Rakyat Indonesia), Bank Mandiri, BNI (Bank Nasional Indonesia), BTN (Bank Tabungan Negara), Bank Danamon, Bank Sinar Mas, BTPN (Bank Tabungan Pensiun Negara).

Dari 12 responden yang telah diwawancarai, $60 \%$ UMKM mengakses pembiayaan mikro sedangkan yang $40 \%$ memilih tidak mengakses pembiayaan mikro. UMKM Kuliner di Pasar Semawis yang mengakses pembiayaan mikro memiliki preferensi sendiri-sendiri terhadap pembiayaan mikro. Sebanyak 50\% UMKM mengakses pembiayaan mikro dari bank Mandiri , 25\% mengkases pembiayaan mikro dari BRI, dan $25 \%$ mengakses pembiayaan mikro dari BTPN . Secara umum mereka mengaku bahwa prosedur dalam mengakes pembiayaan mikro tidaklah sulit, tergolong mudah dan sederhana.

\section{Faktor Pendukung dan Penghambat dalam Mengakses Pembiayaan Mikro}

Terdapat beberapa faktor yangmenjadi pendukung UMKM kuliner di Pasar Semawis dalam mengakses pembiayaan mikro. Faktor tersebut antara lain adalah syarat-syarat pinjaman, jangka waktu penulasan, pelayanan, dan prosedur peminjaman. Keempat faktor tersebut menjadi faktor utama yang dapat mendukung akses terhadap pembiayaan mikro para pelaku UMKM kuliner di Pasar Semawis. Berdasarkan pengalaman responden, syarat dan prosedur dalam mengajukan pinjaman mikro tergolong mudah asalkan memiliki ijin usaha yang jelas maka sudah dapat mengajukan pinjaman di lembaga keuangan mikro. Pinjaman mikro biasanya tidak mensyaratkan agunan. Ijin usaha menjadi pengganti agunan, sehingga sangat memudahkan. Di Kota Semarang ijin usaha UMKM atau disebut IUMK ini dilayani secara gratis oleh Pemerintah Kota Semarang. sehingga realisasi pembiayaan mikro menjadi lebih mudah. Yang kedua, dari segi pelayanan, responden merasa pelayanan yang diberikan karyawan lembaga pembiayaan mikro baik dan ramah, dapat membantu proses tata cara yang disyaratkan oleh pihak bank sehingga berjalan dengan lancar. Beberapa bank yang 
menawarkan pembiayaan mikro bahkan bersedia mendatangi UMKM secara langsung, sehingga UMKM tidak perlu meninggalkan usahanya untuk mengurus pinjaman. Jangka waktu pelunasan yang diberikan untuk menulasi pinjaman yang diinginkan oleh UMKM adalah jangka waktu sekitar $2-5$ tahun sehingga cicilan pinjaman per bulan tidak terlalu memberatkan.

\section{Faktor Penghambat}

Selain faktor pendukung yang telah yang disebutkan di atas, ada beberapa hal yang menjadi penghambat yang dialami UMKM kuliner Pasar Semawis dalam mengajukan pembiayaan mikro seperti yang disebutkan di awal bahwa mereka tidak mengakses pembiayaan mikro dikarenakan ingin menghindari resiko apabila nantinya tidak mampu melunasi pinjaman. Selain itu, hambatan juga dapat berasal dari lembaga pembiayaan mikro itu sendiri. Faktor pertama adalah proses pencairan dana memakan waktu yang lama, yaitu sekitar 2 minggu menjadi faktor hambatan yang paling banyak disebutkan. Dikarenakan dalam mengajukan pinjaman pembiayaan mikro, calon debitur harus mengikuti tata cara dan memenuhi segala persyaratan yang diberikan oleh pihak lembaga keuangan. Proses administrasi dan pencairan dana membutuhkan waktu beberapa hari sampai dana bisa sampai ke tangan debitur. Sedangkan mereka membutuhkan dana dengan cepat untuk kebutuhannya. Faktor kedua, ada responden yang menyebutkan bahwa mereka tidak mempunyai agunan meskipun hanya berupa ijin usaha yaitu IUMK, ada beberapa pelaku UMKM yang belum memilikinya. Beberapa bank ada yang tetap mensyaratkan agunan berupa, surat kepemilikan kendaraan misalnya sehingga dirasakan cukup memberatkan bagi pelaku usaha skala mikro seperti mereka. Beban bunga pinjaman yang masih diatas $7 \%$ dirasakan cukup berat bagi para pelaku UMKM tersebut.Selain itu, terdapat penghambat dari diri UMKM itu sendiri yaitu kekhawatiran mereka tidak mampu melunasi pinjaman tepat waktu, takut disita yang akan membuat mereka malu, sehingga sebagian pelaku UMKM kuliner di Pasar Semawis lebih mengandalkan modal milik sendiri dari tabungan yang mereka kumpulkan. 


\section{Stimulasi Pembiayaan Mikro Terhadap Usaha}

Manfaat positif paling besar yang dirasakan para pedagang kuliner Semawis dari pembiayaan mikro adalah meningkatkan omzet dan meningkatkan keuntungan. Dari adanya pinjaman mikro sebagai tambahan modal usaha, mereka dapat menambah persediaan dan berjualan lebih lama terutama saat pasar Semawis ramai pengunjung pada waktu weekend. Pembiayaan mikro juga memungkinkan pelaku UMKM untuk menambah asset untuk mendukung operasional usaha mereka seperti membeli gerobak, tenda bahkan kendaraan.Pembiayaan mikro dirasakan oleh pelaku UMKM Kuliner di Pasar Semawis telah menstimulus kinerja usaha mereka.

\section{PENUTUP}

Berdasarkan hasil penelitian yang telah dilakukan, maka didapatkan kesimpulan sebagai berikut:

a. Para UMKM Kuliner di Pasar Semawis Semarang rata - rata telah mengenal pembiayaan mikro dan memiliki akses untuk menggunakan pembiayaan mikro. Namun dari seluruh responden, hanya sebagian yang mengakses pembiayaan mikro tersebut. Para pelaku UMKM Kuliner khawatir dengan risiko pinjaman, takut tidak bisa melunasi pinjaman sehingga sebagian pelaku UMKM Kuliner di Pasar Semawis memilih menjalankan usaha dengan modal sendiri seadanya. Hal ini menyebabkan UMKM Kuliner di Pasar Semawis menjadi kurang berkembang.

b. Pembiayaan mikro yang dikenal oleh para UMKM kuliner di Pasar Semawis rata rata adalah lembaga keuangan mikro yang berasal dari perbankan seperti BTN, Bank Mandiri, BRI, BNI, Bank Danamon, dan lain-lain. Dikarenakan dari pihak perbankan sekarang sudah banyak yang menawarkan pembiayaan mikro secara langsung mendatangi para pelaku UMKM. Mereka kurang mengenal lembaga keuangan mikro non perbankan yang menyediakan pinjaman untuk usaha mikro. Sedangkan mereka yang telah mengakses pembiayaan mikro, mengakses pinjaman modal yang berasal dari lembaga keuangan mikro perbankan antara lain BTPN, BRI, dan Bank Mandiri. 
c. Faktor penghambat yang dihadapi oleh UMKM kuliner Semawis dalam mengakses pembiayaan mikro adalah proses pencairan dana yang membutuhkan waktu yang cukup lama, faktor agunan akibat kurangnya asset untuk dijadikan jaminan dan kekhawatiran mengambil risiko

d. Sedangkan faktor pendukung bagi UMKM Pasar kuliner di Semawis dalam mengakses pinjaman mikro adalah prosedur yang mudah serta pelayanan yang baik.

e. Faktor-faktor yang dipertimbangkan oleh UMKM Kuliner di Pasar Semawis untuk menggunakan pembiayaan mikro adalah bahwa mereka dapat meningkatkan jumlah modal untuk mengembangkan usaha, terutama membeli perlengkapan usaha seperti gerobak, tenda dan lain-lain.

f. Dampak positif yang dapat dirasakan oleh pelaku UMKM Kuliner di Pasar Semawis adalah dengan pembiayaan mikro ini mereka dapat menambah asset yang mendukung usaha mereka dan dapat meningkatkan omzet penjualan mereka, sehingga meningkatkan keuntungan mereka.

\section{Saran}

UMKM Kuliner di Pasar Semawis sudah mengenal dan memiliki akses terhadap pembiayaan mikro terutama dari perbankan. Hanya keberanian untuk mengembangkan usaha dengan menambah modal dari pembiayaan mikro yang masih kurang. Para pelaku UMKM kurang berani mengambil risiko sehingga lebih baik menjalankan usahanya dengan modal seadanya, akibatnya uasah para UMKM Kuliner di Pasar Semawis kurang berkembang. Pihak Perbankan maupun non perbankan perlu memberikan sosialisasi dan edukasi mengenai pengelolaan dan manfaat pembiayaan mikro bagi pengembangan usaha para pelaku UMKM agar mereka memiliki keberanian dan kemampuan menggunakan fasilitas pembiyaan mikro untuk mengembangkan usaha mereka. 


\section{DAFTAR PUSTAKA}

Anggraeni, L., Puspitasari, H., Ayubbi, S. El, \& Wiliasih, R. (2013). Akses UMKM Terhadap Pembiayaan Mikro Syariah dan Dampaknya Terhadap Perkembangan Usaha : Kasus BMT Tadbiirul Ummah, Kabupaten Bogor The Access of MSME towards Islamic Microfinancing and Its Impact on Business Development: A Case of BMT Tadbiirul Ummah, Bogor, $I$ (1), 56-67.

Esterberg, Kristin G. 2002. Qualitative Methods in Social Research. New York: McGrow Hill.

Ilmiah, J. 2015. Terhadap Sumber Pembiayaan Usaha (Studi di Pasar Tradisional Dinoyo Kota Malang).

Ini Alasan UKM Enggan Akses Dana Pebankan. 2015. [Online]. Tersedia di: http://www.smartbisnis.co.id/content/read/berita-bisnis/umum/ini-alasan-ukmenggan-akses-dana-perbankan. Diakses 8 November 2016.

Kamus Besar Bahasa Indonesia. [Online]. Tersedia di: http://kbbi.web.id/. Diakses 5 Oktober 2016.

Kementrian Koperasi dan UKM Republik Indonesia. 2015. Data UMKM 2015. [Online]. Tersedia di: http://www.depkop.go.id/berita-informasi/data-informasi/. Diakses 10 Oktober 2016.

Permodalan, S., Faktor, D. A. N., Mempengaruhinya, Y., Provinsi, D. I., Faktor,F., Mempengaruhinya, Y., \& Provinsi, D. I. (2016). AKSESIBILITAS PETANI PADI SAWAH TERHADAP, (July).

Republik Indonesia. 2008. Undang-Undang No. 20 Tahun 2008 tentang Usaha Mikro, Kecil, dan Menengah.

Saraswati, Birgitta Dian, Sotya Fevriera, dan Sally Dwijayanti. 2011. Jurnal Akuntansi Manajemen. Vol. 22, No. 3:247-255.

Sugiyono. 2012. Metode Penelitian Kuantitatif, Kualitatif dan R\&D. Bandung: Alfabeta.

Wafirotin, Khusnatul Zulfa, dan Asis Riat Winanto. 2015. Analisis Akses Kredit Usaha Sektor Informal di Kota Ponorogo.

76\% UMKM Jateng Sulit Dapat Modal. 2016. [Online]. Tersedia di: http://economy.okezone.com/read/2016/04/29/320/1375992/76-umkm-jatengsulit-dapat-modal. Diakses 11 Januari 2017. 